\title{
THE EFFECTS OF CADMIUM ON THE BIOCHEMICAL AND PHYSIOLOGICAL PARAMETERS OF ERUCA SATIVA
}

\author{
Yasemin OzDener Kompe* and Ahmet SAgiroglu \\ Department of Biology, Faculty of Arts and Sciences, University of Ondokuz mayis, \\ Samsun, Turkey
}

(Received: March 21, 2016; accepted: May 6, 2016)

\begin{abstract}
In this study, Eruca sativa (Rocket) seedlings were treated with different cadmium (Cd) concentrations $\left(0,150,300\right.$ and $\left.450 \mu \mathrm{g} \cdot \mathrm{g}^{-1}\right)$. The effects of Cd on lipid peroxidation, enzymatic (APx, CAT, GPX, SOD) and non-enzymatic antioxidants (total ascorbate, dehydroascorbate, ascorbate, non-protein thiol), fresh and dry masses, water content were determined. Also, Cd content of the leaves and the roots were analysed. The highest cadmium accumulation of leaves was at $450 \mu \mathrm{g} \cdot \mathrm{g}^{-1} \mathrm{Cd}$ treatment and the accumulation was 2.62 times greater than those in the roots. The translocation factor was 3.89 at $300 \mu \mathrm{g} \cdot \mathrm{g}^{-1} \mathrm{Cd}$ treatment. Cd treatments caused decreases of fresh, dry mass and water content of leaves and roots. Malondialdehyde content, which is an index of lipid peroxidation, was increased in proportion with the increase in Cd. While there was not change in the activity of GPX according to control, a decrease in activities of SOD, CAT and APX were observed with the increase of cadmium concentration. Although a significant increase in the amounts of non-protein thiol groups and proline were observed in $450 \mu \mathrm{g} \cdot \mathrm{g}^{-1}$ $\mathrm{Cd}$ treated plants, $\mathrm{Cd}$ did not lead to a significant change in AsA, DHA and total AsA contents. According to the results of the research, E. sativa may be a Cd hyperaccumulator plant and we suggest that the plant may be a candidate plant for remediation of Cd-contaminated soil.
\end{abstract}

Keywords: Eruca sativa - cadmium - hyperaccumulator - oxidative stress

\section{INTRODUCTION}

Heavy metals are significant environmental pollutants and have serious effects on soil and water quality, plant and animal nutrition, as well as human health [26, 30]. Some heavy metals, such as $\mathrm{Cu}, \mathrm{Zn}, \mathrm{Mn}, \mathrm{Ni}$ and $\mathrm{Mo}$, are essential micronutrients for plants, but all metals are toxic to organisms at high concentrations [12, 26, 34, 38]. Cadmium (Cd) is non-essential and toxic to all organisms $[5,10]$. It is well known that $\mathrm{Cd}$ toxicity causes alterations such as membrane damage, disruption of electron transport, inhibition/activation of enzymes and interaction with nucleic acids and photosynthesis $[7,8,21]$. Plants undergo several physiological/biochemical changes so as to manage a balance between reactive oxygen species and their antioxidants assisted metabolism $[3,4,16]$. ROS may cause membrane integrity weakening, elevated elec-

*Corresponding author; e-mail address: yasemino@omu.edu.tr 
trolyte leakage (EL), oxidation of proteins and membrane lipids [17, 18]. On the other hand, plants are equipped with an efficient antioxidant defense system, comprising both enzymatic (glutathione reductase, GR; glutathione peroxidase, GPx; guaiacol peroxidase GPOX; catalase, CAT; ascorbate peroxidase, APX) and nonenzymatic (reduced glutathione, GSH, and ascorbate, AsA pools) components, which control, directly or indirectly, the ROS-accrued potential anomalies [17]. Many environmental stresses have been reported to increase the level of proline in plants, such as heavy metals, temperature and drought $[9,14,33]$. The family Brassicaceae is known to be a family containing many metal accumulating species. The crop species of Brassicaceae can accumulate some of the heavy metals [11, 37]. Eruca sativa (Brassicaceae), one of the varieties of mustard, is an annual or biannual herb. It is extensively consumed in some European countries, e.g. Italy and Turkey. Eruca sativa was determined to be tolerant against some heavy metals [29]. Based on this information, the aim of the research, was to determine effects of $\mathrm{Cd}$ on biochemical and physiological parameters of the leaves and the roots of E. sativa, and tolerance level to $\mathrm{Cd}$ or the accumulation ratio of parts of the plant.

\section{MATERIALS AND METHODS}

\section{Plant material and Cd application}

Eruca sativa (Istanbul Rocket) seeds were sown in the pots, each of which $(20 \times 12 \times$ $18 \mathrm{~cm}$ ) contained 20-30 seeds and the mixture of torf:perlite:sand in a ratio of 4:2:1. The torf was dried at $60{ }^{\circ} \mathrm{C}$ and then was grounded. Commercial torf was used in this study. Before the exposure period, $\mathrm{Cd}$ content of the growth medium was determined using UNICAM 929 model Atomic Absorbtion Spectrometer (UNICAM, UK). Seven days after germination, seedlings, ten per pot, were transferred into other pots of the same size, containing the same mixture. Three pots were prepared and 30 plants were grown for each Cd treatments. All the pots were first supplemented with full strength hoagland solution. Seedlings with 3-4 leaves were treated with one of the varying $\mathrm{Cd}$ concentrations $\left(0,150,300,450 \mu \mathrm{g} \cdot \mathrm{g}^{-1}\right.$ dried growth medium). To obtain the final concentration of $150,300,450 \mu \mathrm{g} \cdot \mathrm{g}^{-1}$ per $\mathrm{g}$ of dry medium (totally $500 \mathrm{~g}$ ), Cd $\left(\mathrm{CdCl}_{2} \cdot 2.5 \mathrm{H}_{2} \mathrm{O}\right.$, Sigma) was weighed and solved in a liter of water. During this treatment, $\mathrm{Cd}$ and Hoagland solutions were added to the seedlings twice a week until one liter Cd solution ended completely. Control groups were only supplied with Hoagland solution. The seedlings were harvested two days after completed one liter Cd solution treatment.

Five plants were randomly selected from each pot. The roots of each seedling were washed in the distillated water. Leaf and root fresh weights were measured. Later, these leaves and roots were dried at $70{ }^{\circ} \mathrm{C}$, their dried weights and the water contents were determined. The other plants in the pots were used for biochemical analysis. The youngest 3-4 leaves of the plants were collected, frozen in liquid nitrogen and kept at $-80^{\circ} \mathrm{C}$ for analysis. 


\section{Cadmium contents of roots and leaves}

Cd content was determined using an atomic absorption spectrometer (UNICAM 929 Atomic Absorption Spectrometer) [2]. The translocation factor, which is defined as the ratio of cadmium concentrations in the leaves to those in the roots and "TF", depicts effectiveness of a plant in the translocation [36]. Translocation factors for the parts of E. sativa are calculated as follow

$L C d=C d$ content of Leaves,

$$
T F=L C d / R C d .
$$

$R C d=C d$ content of Roots,

\section{Lipid Peroxidation}

The level of lipid peroxidation products (malondialdehyde) was measured by the procedure based on the method of Heath and Packer [19].

\section{Enzyme activity measurements}

The leaves $(0.2 \mathrm{~g})$ were placed into liquid nitrogen and then homogenized in $5 \mathrm{~mL} 50$ $\mathrm{mM}$ K-phosphate buffer ( $\mathrm{pH} 7.0$ ) containing $1 \mathrm{mM}$ ethylene diamine tetraaceticacid (EDTA) and $0.1 \%(\mathrm{w} / \mathrm{v})$ insoluble polyvinyl polypyrrolidone (PVPP), using glass powder and a prechilled mortar and pestle. The homogenate was centrifuged at $15,000 \mathrm{~g}$ for $20 \mathrm{~min}$ at $+4{ }^{\circ} \mathrm{C}$. The final supernatant was stored at $-20{ }^{\circ} \mathrm{C}$ before use for enzyme activity measurements.

Catalase (EC 1.11.1.6) activity was determined by monitoring the degradation of $\mathrm{H}_{2} \mathrm{O}_{2}$ at $240 \mathrm{~nm}$ over 2 min against a supernatant-free blank. Enzyme specific activities were expressed as $\mu \mathrm{mol}$ of $\mathrm{H}_{2} \mathrm{O}_{2}$ oxidized $\mathrm{min}^{-1} \mathrm{mg}^{-1}$ protein [1].

Superoxide dismutase (EC 1.15.1.1) activity was measured according to Madamanchi et al. [22], and expressed in enzyme unit according to Madhava Rao and Srestry [23].

Guaiacol peroxidase (EC 1.11.1.7) activity was measured by following the change of absorption at $470 \mathrm{~nm}$ due to guaiacol oxidation (extinction coefficent $25.5 \mathrm{mM}^{-1}$ $\mathrm{cm}^{-1}$ ). Enzyme-specific activity was expressed as $\mu \mathrm{mol}$ of $\mathrm{H}_{2} \mathrm{O}_{2}$ reduced $\mathrm{min}^{-1} \mathrm{mg}^{-1}$ protein [31].

Ascorbate peroxidase (EC 1.11.1.11) was assayed according to Nakano and Asada [27], with minor modifications. The decrease in absorbance at $290 \mathrm{~nm}$ was recorded for $5 \mathrm{~min}$ (extinction coefficient $2.8 \mathrm{mM}^{-1} \mathrm{~cm}^{-1}$ ). The specific activity of enzyme was expressed as $\mu \mathrm{mol}$ ascorbate oxidized $\mathrm{min}^{-1} \mathrm{mg}^{-1}$ protein. 


\section{Prolin content}

The proline contents of the leaf and roots of the sample seedlings were determined according to the method of Claussen [9]. The absorbance of the mixture at $546 \mathrm{~nm}$ were obtained with a spectrophotometer. The proline concentration was determined from a calibration curve obtained with proline (Sigma) and calculated as a fresh weight basis [ $\mu$ mol proline $\left.\left(\mathrm{g} \mathrm{FW}^{-1}\right)\right]$.

\section{Non-protein thiols and ascorbic acid measurement}

Soluble non-protein thiols and total ascorbic acid were measured as described in Cakmak and Marschner [6].

Ascorbic acid assay is based on the reduction of $\mathrm{Fe}^{+3}$ to $\mathrm{Fe}^{+2}$ by ascorbic acid in an acidic solution [6,28], Soluble non-protein thiols were measured with Ellman's reagent [15].

Centrifugation was carried out with a Kubota 5500 model (Kubota Corporation, TOKYO) centrifuge. The spectrophotometric measurements were made with T70 model UV/VIS spectrometer (PG Instruments Ltd. UK).

\section{Statistical analysis}

The data of dry and fresh weights of seedlings were based on three independent experiments (the average values of total fifteen, five seedlings from each pods) and the other seedlings in the three pods were used the biochemical analysis. The results of the biochemical parameters are based on at least six replicates from three independent experiments. The data obtained by the methods described above were subjected to one-way analysis of variance (ANOVA). These analyses were performed using the program SPSS 15.0.

\section{RESULTS}

Cd content of the commercial peat was $1.7 \mu \mathrm{g} \cdot \mathrm{g}^{-1} \mathrm{DW}$. To obtain the final concentration of $150,300,450 \mu \mathrm{g} \cdot \mathrm{g}^{-1}$ per $\mathrm{g}$ of dry medium $(500 \mathrm{~g}), 74.15 \cdot 10^{3} ; 149.15 \cdot 10^{3}$; $224.15 \cdot 10^{3} \mu \mathrm{g} \mathrm{Cd}\left(\mathrm{CdCl}_{2} \cdot 2.5 \mathrm{H}_{2} \mathrm{O}\right.$, Sigma) was weighed, respectively (Cd content of commercial torf $-1.7 \mu \mathrm{g} \cdot \mathrm{g}^{-1}$ was deducted from total amounts of growth medium). In this study, rocket seedlings were treated with control, $150,300,450 \mu \mathrm{g} \cdot \mathrm{g}^{-1} \mathrm{Cd}$ solution and the effect of $\mathrm{Cd}$ on fresh, dried weights and water contents of the plants were determined. The effects of various $\mathrm{Cd}$ are shown in Table 1 . There were statistically significant decreases in the fresh and dried weights according to control group. The water contents of the roots and leaves were significantly decreased at all $\mathrm{Cd}$ treatments (Table 1). Cd accumulation in the roots and leaves were given in Table 2. 
Cd contents of the roots and leaves were increased dramatically depending on increase in the growth medium. Cadmium accumulated in higher concentration in the leaves than in the roots at all $\mathrm{Cd}$ treatment. Translocation factor values which is defined as the ratio of cadmium concentrations in leaves to those in roots showed that $\mathrm{Cd}$ concentration in above ground biomass were 2 or 3 times greater than those in roots. The highest translocation factor, 3.89 , was at $300 \mu \mathrm{g} \cdot \mathrm{g}-1$ Cd treatment (Table 2). As the general description, plant with a translocation factor greater than 1 is considered as accumulator plant. In that case, our results suggested that $E$. sativa may be a candidate for $\mathrm{Cd}$ accumulator plant. Lipid peroxidation is the first and the most important marker of oxidative stress or oxidative damage. In the rocket leaves, lipid peroxidation, which is measured as malondialdehyde (MDA) content, increased significantly at all $\mathrm{Cd}$ concentrations $(p<0.05)$ (Table 3 ). Activities of all investigated

Table 1

The effects of $\mathrm{Cd}$ on the water content, fresh and dried weihts of Eruca sativa seedlings

\begin{tabular}{|c|c|c|c|}
\hline $\begin{array}{c}\mathrm{Cd} \\
\left(\mu \mathrm{g} \cdot \mathrm{g}^{-1}\right)\end{array}$ & $\begin{array}{c}\mathrm{FW} \\
\left(\mathrm{g} \cdot \text { the plant }^{-1}\right)\end{array}$ & $\begin{array}{c}\text { DW } \\
\left(\mathrm{g} \cdot \text { the plant }^{-1}\right)\end{array}$ & $\begin{array}{c}\text { Water content } \\
\left(\mathrm{g} \cdot \text { the plant }^{-1}\right)\end{array}$ \\
\hline 0 & $2.32 \pm 0.240 \mathrm{aa}$ & $0.13 \pm 0.010 \mathrm{aa}$ & $2.19 \pm 0.230 \mathrm{aa}$ \\
\hline 150 & $1.64 \pm 0.470 \mathrm{bc}$ & $0.10 \pm 0.006 \mathrm{ab}$ & $1.53 \pm 0.110 \mathrm{bc}$ \\
\hline 300 & $1.50 \pm 0.420 \mathrm{bc}$ & $0.09 \pm 0.007 \mathrm{ab}$ & $1.41 \pm 0.100 \mathrm{bc}$ \\
\hline 450 & $1.27 \pm 0.470 \mathrm{cc}$ & $0.09 \pm 0.009 \mathrm{bb}$ & $1.18 \pm 0.100 \mathrm{cc}$ \\
\hline
\end{tabular}

$(P \leq 0.05, N=15)$.

Table 2

Bioaccumulation of cadmium in Eruca sativa roots and leaf

\begin{tabular}{|c|c|c|c|}
\hline $\begin{array}{c}\text { Concentration } \\
\left(\mu \mathrm{g} \cdot \mathrm{g}^{-1}\right)\end{array}$ & $\begin{array}{c}\text { Leaf } \\
\mathrm{Cd}\left(\mu \mathrm{g} \cdot \mathrm{g}^{-1}\right)\end{array}$ & $\begin{array}{c}\text { Roots } \\
\mathrm{Cd}\left(\mu \mathrm{g} \cdot \mathrm{g}^{-1}\right)\end{array}$ & TF \\
\hline $1.7($ control $)$ & $0.617 \pm 0.005 \mathrm{a}$ & $0.247 \pm 0.006 \mathrm{a}$ & 2.49 \\
\hline 150 & $16.93 \pm 0.008 \mathrm{~b}$ & $6.10 \pm 0.006 \mathrm{~b}$ & 2.77 \\
\hline 300 & $30.17 \pm 0.005 \mathrm{c}$ & $7.75 \pm 0.046 \mathrm{c}$ & 3.89 \\
\hline 450 & $58.51 \pm 0.011 \mathrm{~d}$ & $22.31 \pm 0.009 \mathrm{~d}$ & 2.62 \\
\hline
\end{tabular}

$(P \leq 0.05, N=9)$.

Table 3

The effect of $\mathrm{Cd}$ on the lipid peroxidation and non-protein thiol

\begin{tabular}{|c|c|c|}
\hline $\begin{array}{c}\text { Cd concentration } \\
\left(\mu \mathrm{g} \cdot \mathrm{g}^{-1}\right)\end{array}$ & $\begin{array}{c}\text { Lipid peroxidation } \\
\text { MDA }\left(\mu \mathrm{g} \cdot \mathrm{g}^{-1} \mathrm{FW}\right)\end{array}$ & $\begin{array}{c}\text { Non-protein thiol } \\
\left(\mu \mathrm{g} \cdot \mathrm{g}^{-1} \mathrm{FW}\right)\end{array}$ \\
\hline $1.7($ control$)$ & $22.8 \pm 3.55 \mathrm{~b}$ & $0.023 \pm 0.009 \mathrm{~b}$ \\
\hline 150 & $35.33 \pm 6.8 \mathrm{a}$ & $0.024 \pm 0.004 \mathrm{~b}$ \\
\hline 300 & $33.38 \pm 4.9 \mathrm{ab}$ & $0.026 \pm 0.01 \mathrm{ab}$ \\
\hline 450 & $40.40 \pm 8.05 \mathrm{a}$ & $0.041 \pm 0.015 \mathrm{a}$ \\
\hline
\end{tabular}

$(P \leq 0.05, N=6) ; \pm$ : standard deviation. 


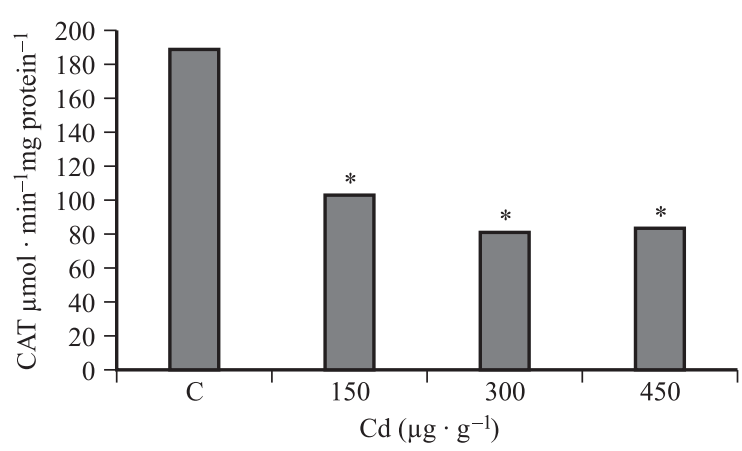

Fig. 1. Effect of various Cd concentrations on activity of CAT in leaves E. sativa. Asteriks were used to identify the levels of significance in the difference between control and treatments: ${ }^{*} P<0.05$

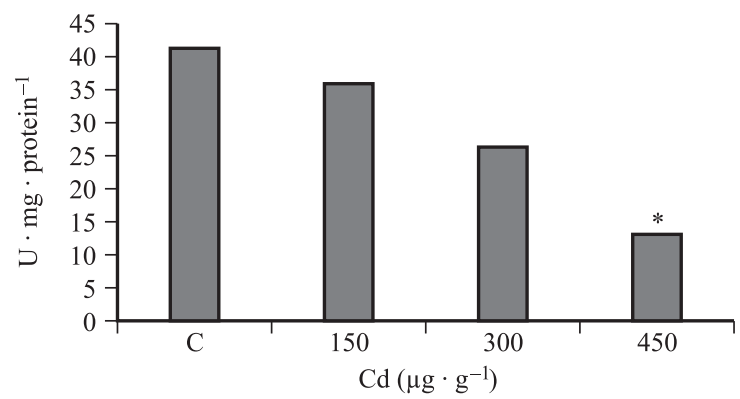

Fig. 2. Effect of various Cd concentrations on activity of SOD in leaves E. sativa. Asteriks were used to identify the levels of significance in the difference between control and treatments: ${ }^{*} P<0.05$

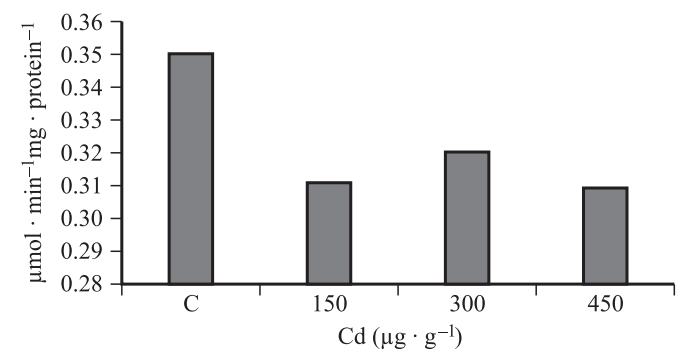

Fig. 3. Effect of various Cd concentrations on activity of GPX in leaves E. sativa 


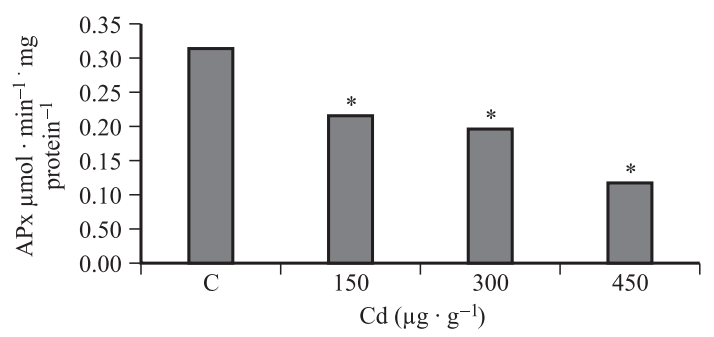

Fig. 4. Effect of various Cd concentrations on activity of APx in leaves E. sativa. Asteriks were used to identify the levels of significance in the difference between control and treatments: ${ }^{*} P<0.05$

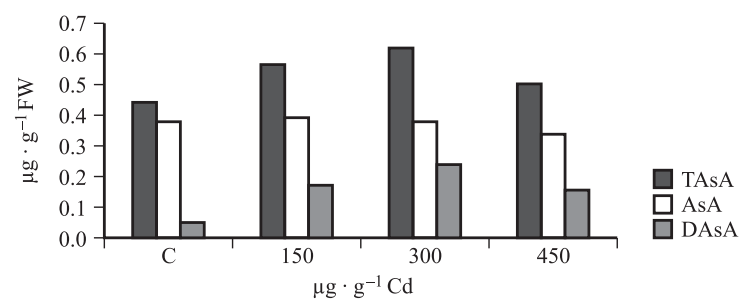

Fig. 5. The content of AsA, DAsA and total ascorbate (AsA+DAsA) in leaves of E. sativa

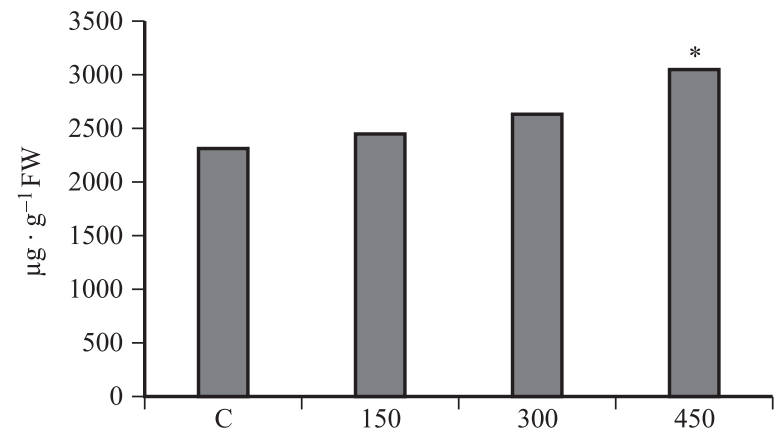

Fig. 6. The content of proline in the leaves of E. sativa. Âsteriks were used to identify the levels of significance in the difference between control and treatments: ${ }^{*} P<0.05$

antioxidative enzymes decreased compared to control, decreases in activities of CAT and APx were significant at all Cd concentrations (Figs 1 and 4). Guaiacol peroxidase activity which was based on the oxidation of guaiacol using hydrogen peroxide did not change (Fig. 3). Also, SOD activity significantly decreased at $450 \mu \mathrm{g} \cdot \mathrm{g}{ }^{-1} \mathrm{Cd}$ (Fig. 2). Ascorbate and non-protein thiols are cellular non-enzymatic antioxidants which play an important role in detoxification of ROS. The increase of the amounts of total ascorbate (TASA), dehydroascorbate (DASA) and reduced ascorbate (ASA) was not statistically significant at the all $\mathrm{Cd}$ treatments (Fig. 5). Non-protein thiol groups significantly increased at $450 \mu \mathrm{g} \cdot \mathrm{g}^{-1} \mathrm{Cd}$ treatment (Table 3). Proline content 
of leaves at the highest applied concentration of cadmium $\left(450 \mu \mathrm{g} \cdot \mathrm{g}^{-1} \mathrm{Cd}\right)$ increased significantly (Fig. 6).

\section{DISCUSSION}

In this study, the effects of $\mathrm{Cd}$ treatments on different biochemical and physiological parameters of E. savita were different. Cd treatments caused oxidative stress. Considerable amounts of cadmium accumulated in the leaves of rocket. Masarovičova et al. [24] suggested that plants with Translocation Factor higher than 1 were considered as hyperaccumulator. In this research, TF of the seedlings for all Cd treatments was higher than 1 . In that case, we may suggest that $E$. sativa is a hyperaccumulator plant for cadmium. Under heavy metal stress, $\mathrm{H}_{2} \mathrm{O}_{2}$ and $\mathrm{O}_{2}^{-}$, via the Haber-Weiss reaction, are converted into highly reactive $\mathrm{OH}^{-}$radical and this causes lipid peroxidation [4]. The analysis showed that lipid peroxidation, the most distinctive indication of oxidative stress, increased due to the increase in cadmium concentration. A similar responses were observed in plants treated with $\mathrm{Cd}$ and the other heavy metal $[29,32,35]$. The enzymes, such as SOD, CAT, PODx are considered to play an important role in the cellular defense mechanisms against ROS caused by heavy metal toxicity. Superoxide dismutase is a key enzyme in protecting cells against oxidative stress. This enzyme catalyses the dismutation of $\mathrm{O}_{2}^{-}$to $\mathrm{H}_{2} \mathrm{O}_{2}$ and $\mathrm{O}_{2}$ [22, 35]. In this study, SOD activity decreased in all $\mathrm{Cd}$ concentrations when compared with that of the control but the decrease in $450 \mu \mathrm{g} \cdot \mathrm{g}^{-1}$ was significant statistically. Similarly, it was reported in the other researches that SOD activity decreased in toxic concentrations of some heavy metals $[13,29]$. Cd is a redox inactive metal and it has no direct effect on the SOD activity. But Fe-SOD and $\mathrm{Cu} / \mathrm{Zn}-\mathrm{SOD}$ are both sensitive to $\mathrm{H}_{2} \mathrm{O}_{2}$. For this reason, SOD isoforms could be inactivated by Cd [35]. In addition, excess of $\mathrm{Cd}$, by inhibiting the uptaking of minerals such as $\mathrm{Cu}, \mathrm{Mn}$, Fe, may affect the synthesis of these isoenzymes containing these metals [35]. It has been reported that a number of oxidative factors, as excess $\mathrm{Cd}$, causing formation of $\mathrm{H}_{2} \mathrm{O}_{2}$ may play a role in the inhibition of SOD. CAT, APx and GPX decreased in all Cd treatments. GPX is an enzyme bound to the cell wall. [25]. The reason of decrease of activity of GPX in the leaves of Eruca sativa may be the measured accumulation of Cd in the leaves. Similarly, CAT and APX activities decreased. Because $\mathrm{O}_{2}^{-}$inhibits enzyme protein, decrease in CAT activity occurs [6]. But the amounts of non-enzymatic antioxidants, such as non-protein thiol, ascorbate and proline, increased significantly. Non-protein thiols, which contain a high percentage of cysteine sulfhydryl residues play an important role in heavy metal detoxification process in plants. Similar results has also been reported in Cd stressed Arabidopsis thaliana [20] and Brassica oleracea var. acephala [13]. Proline is a regulator of osmotic potential of the cells under various environmental stresses, furthermore it functions as free radical scavenger and an activator of detoxification mechanism against $\mathrm{Cd}$ toxicity. Despite high concentrations of $\mathrm{Cd}$ accumulated in the roots and leaves, morphological changes did not occur in E. sativa seedlings. This was probably because $\mathrm{Cd}$ was accumulated in cellular 
compartments. Also in Thlaspi caerulescens (hyperaccumulator of $\mathrm{Cd}$ ) cadmium accumulated without visible phytotoxic effect on the leaves [11]. Translocation factor was higher than 1 . The value $(\mathrm{TF}>1)$ indicates that the plant is a hyperaccumulator. Otherwise, the results showed that enzymatic and non-enzymatic antioxidant defense system in the leaves resisted $\mathrm{Cd}$ stress and thus minimized the cellular damage. The enzymatic proteins were probably inhibited by $\mathrm{Cd}$ but non-enzymatic antioxidants scavenged the ROS induced by $\mathrm{Cd}$ in leaves of $E$. sativa and the plant could eliminate the toxic effect of $\mathrm{Cd}$. Consequently, E. sativa is recommended as a candidate plant for the remediation of $\mathrm{Cd}$ contaminated sites.

\section{REFERENCES}

1. Aebi, H. (1984) Catalase in vitro. Methods Enzymol. 105, 121-126.

2. Allen, S. E., Grimshaw, H. M., Parkinson, J. A., Quarmby, C., Roberts, J. D. (1986) Chemical analysis. In: Chapman, S. B. (ed.) Methods in Plant Ecology. Blackwell Science, Oxford, pp. 411-466.

3. Anjum, N. A., Ahamd, I., Mohmood, I., Pacheco, M., Duarte, A. C., Pereira, E., Umar, S., Ahmad, A., Khan, N. A., Iqbal, M., Prasad, M. N. V. (2012) Modulation of glutathione and its related enzymes in plants' responses to toxic metals and metalloids - a review. Environ. Exp. Bot. 75, 307-324.

4. Apel, K., Hirt, H. (2004) Reactive oxygen species: metabolism oxidative stress, and signaling transduction. Annu. Rev. Plant Biol. 55, 373-399.

5. Benavides, M. P., Gallego, S. M., Tomaro, M. L. (2005) Cadmium toxicity in plants. Braz. J. Plant Physiol. 17, 21-34.

6. Cakmak, I., Marschner, H. (1992) Magnesium deficiency and high light intensity enhance activities of superoxide dismutase, ascorbate peroxidase, and glutathion reductase in bean leaves. Plant Physiol. 98, 1222-1227.

7. Chaoui, A., Mazhoudi, S., Ghorbal, M. H., El Ferjani, E. (1997) Cadmium and zinc induction of lipid peroxidation and effects on antioxidant enzyme activities in bean (Phaseolus vulgaris L.). Plant Sci. 127, 139-147.

8. Chen, Y. X., He, Y. F., Luo, Y. M., Yu, Y. L., Lin, Q., Wong, M. H. (2003) Physiological mechanism of plant roots exposed to cadmium. Chemosphere 50, 789-793.

9. Claussen, W. (2005) Proline as a measure of stress in tomato plants. Plant Sci. 168, 241-248.

10. Clemens, S. (2006) Toxic metal accumulation, responses to exposure and mechanisms of tolerance in plants. Biochimie. 88, 1707-1719.

11. Cosio, C., Martinoia, E., Keller, C. (2004) Hyperaccumulation of cadmium and zinc in Thlaspi caerulescens and Arabidopsis halleri at the leaf cellular level. Plant Physiol. 134, 716-725.

12. Demchenko, N. P., Kalimova, I. B., Demchenko, K. N. (2005) Effect of nickel on growth, proliferation, and differentiation of root cells in Triticum aestivum seedlings. Russian J. Plant Physiol. 52, 220-228.

13. Demir, E., Ozdener, Y. (2015) The effects of cadmium on the antioxidative responses of leaves of Brassica oleracea var. acephala. Fresenius Env. Bull. 24, 4729-4737.

14. Dhir, B., Sharmila, P., Saradhi, P. P. (2004) Hydrophytes lack potential to exhibit cadmium stress induced enhancement in lipid peroxidation and accumulation of proline. Aquat. Toxicol. 66, 141-147.

15. Ellman, G. L. (1959) Tissue sulfhydryl groups. Arch. Biochem. Biophys. 82, 70-77.

16. Gill, S. S., Tuteja, N. (2010) Reactive oxygen species and antioxidant machinery in abiotic stress tolerance in crop plants. Plant Physiol. Biochem. 48, 909-930.

17. Gill, S. S., Anjum, N. A., Hasanuzzaman, M., Gill, R., Trivedi, D. K., Ahmad, I., Pereira, E., Tuteja, N. (2013) Glutathione and glutathione reductase: a boon in disguise for plant abiotic stress defense operations. Plant Physiol. Biochem. 70, 204-212. 
18. Gupta, M., Cuypers, A., Vangrosveld, J., Clisters, H. (1999) Copper affect the enzymes of the ascorbate-glutathione cycle and its related metabolites in the roots of Phaseolus vulgaris. Physiol. Plant. 106, 262-267.

19. Heath, R. L., Packer, L. (1968) Photoperoxidation in isolated chloroplasts. I. Kinetics and stoichiometry of fatty acid peroxidation. Arch. Biochem. Biophys. 125, 189-198.

20. Lee, S., Petros, D., Moon, J. S., Ko, T. S., Goldsbrough, P. B., Korban, S. S. (2003) Higher levels of ectopic expression of Arabidopsis phytochelatin synthase do not lead to increased cadmium tolerance and accumulation. Plant Physiol. Biochem. 41, 903-910.

21. Leon, A. M., Palma, J. M., Corpas, F. J., Gomez, M., Romero-Puertas, M. C., Chatterjee, D., Mateos, R. M., del Rio, L. A., Sandalio, L.M. (2002) Antioxidative enzymes in cultivars of pepper plants with different sensitivity to cadmium. Plant Phys. Biochem. 40, 813-820.

22. Madamanchi, N. R., Donahue, J., Cramer, C. L., Alscher, R. G., Pedersen, K. (1984) Differential response of $\mathrm{Cu}, \mathrm{Zn}$ superoxide dismutases in two pea cultivars during a short term exposure to sulphur dioxide. Plant Mol. Biol. 26, 95-103.

23. Madhava Rao, K. V., Srestry, T. V. S. (2000) Antioxidative parameters in the seedlings of pigeon pea (Cacanus cajan (L.) Millspaugh) in response to Zn and Ni stresses. Plant Sci. 157, 113-128.

24. Masarovičova, E., Kralova, K., Kummerova, M. (2010) Principles of classification of medicinal plants as hyperaccumulators or excluders. Acta Physiol. Plant. 32, 823-829.

25. Mishra, S., Srivastava, S., Tripathia, R. D., Govindarajan, R., Kuriakose, S. V., Prasad, M. N. V. (2006) Phytochelatin synthesis and response of antioxidants during cadmium stress in Bacopa monnieri L. Plant Physiol. Biochem. 44, 25-37.

26. Munzuroglu, O., Geckil, H. (2002) Effect of metals on seed germination, root elongation, and coleoptile and hypocotyl growth in Triticum aestivum and Cucumis sativus. Arch. Environ. Contan. Toxicol. 43, 203-213.

27. Nakano, Y., Asada, K. (1981) Hydrogen peroxide is scavenged by ascorbate-specific peroxidase in spinach chloroplasts. Plant Cell Physiol. 22, 867-880.

28. Okamura, M. (1980) An improved method for determination of L-ascorbic acid and L-dehydroascorbic acid in blood plasma. Clin. Chim. Acta 103, 259.

29. Ozdener, Y., Aydın, B. K. (2010) The effect of zinc on the growth and physiological and biochemical parameters in seedlings of Eruca sativa (L.) (Rocket). Acta Physiol. Plant. 32, 469-476.

30. Peralta, J. R., Gardea-Torresdey, J. L., Tiemann, K. J., Gomez, E., Arteaga, S., Rascon, E., Parsons, J. G. (2001) Uptake and effects of five heavy metals on seed germination and plant growth in alfalfa (Medicago sativa L.). Bull. Environ. Contam. Toxicol. 66, 727-734.

31. Polle, A., Otter, T., Siefert, F. (1994) Apoplastic peroxidases and lignification in needless of Norvey spruce (Picea abies L.). Plant Physiol. 106, 53-60.

32. Qiu, R. L., Zhao, X., Tang, Y. T., Yu, F. M., Hu, P. J. (2008) Antioxidative response to Cd in a newly discovered cadmium hyperaccumulator, Arabis paniculata F. Chemosphere 74, 6-12.

33. Rai, V., Vajpayee, P., Singh, S. N., Mehrotra, S. (2004) Effect of chromium accumulation on photosynthetic pigments, oxidative stress defence system, nitrate reduction, proline level and eugenol content of Ocimum tenuflorum L. Plant Sci. 167, 1159-1169.

34. Rout, G. R., Das, P. (2003) Effect of metal toxicity on plant growth and metabolism: I. Zinc. Agronomie 23, 3-11.

35. Sandalio, L. M., Dalurzo, H. C., Gómez, M., Romero-Puertas, M. C., del Rio, L. A. (2001) Cadmiuminduced changes in the growth and oxidative metabolism of pea plants. J. Exp. Bot. 52, 2115-2126.

36. Tu, C., Ma, L. Q. (2002) Effects of arsenic concentrations and forms on arsenic uptake by the hyperaccumulator ladder brake. J. Environ. Qual. 31, 641-647.

37. Xiong, Z. T. (1998) Lead uptake and effect on seed germination and plant growth in a Pb hyperaccumulator Brassica pekinensis Rupr. Bull. Environ. Contam. Toxicol. 60, 285-291.

38. Zwolak, I., Zaporowska, H. (2009) Preliminary studies on the effect of zinc and selenium on vanadium-induced cytotoxicity in vitro. Acta Biol. Hung. 60, 55-67. 